\title{
Influence of Language Elements in Understanding Language Context in Social Media
}

\section{Tiara Haninditya Fadillah, Septian Paradesa, Hanna Rizki Nugrahanto, Muhammad Iqbal Priyatna}

Email: tiara.haninditya.fadillah-2020@fib-unair.ac.id septian.paradesa.329487-2020@fib .unair.ac.id hanna.rizki.nugrahanto-2020@ fib.unair.ac.id muhammad.iqbal.priyatna-2020@fib.unair.ac.id

Corresponding Author: Dr. Moses Glorino Rumambo Pandin, SS, M.Sc., M.Phil., e-mail: moses.glorino@fib.unair.ac.id

Address: Jalan Dharmawangsa Dalam Surabaya, Indonesia 60286, Telephone: 031-5035807

\begin{abstract}
:
The purpose of this study was to analyze the causes of misunderstandings related to an article on social media that led to cyberbullying. The research focuses on analyzing the influence of language elements on perspective or the ability to understand the meaning of a piece of writing on social media. This research was conducted using a descriptive method with a quantitative approach. The source of the research data was obtained using data collection techniques with a questionnaire or questionnaire method given to 100 teenagers who were active users of social media with an age range of 13-24 years. The data obtained were analyzed by descriptive statistical analysis techniques. The results showed that: 1). There is a significant influence of language elements such as the choice of diction, the use of punctuation marks, the use of capital letters, and intonation of writing on the understanding of social media users, 2). The literacy ability of social media users has an impact on cases of cyberbullying due to a misunderstanding of an article, 3) All social media has the potential to be a place for cyberbullying, especially Twitter, 4). It is important to note that language elements are used in writing on social media to avoid ambiguity of meaning.
\end{abstract}

Keywords: Social Media, Language Elements, Meaning of Writing, Misconceptions, Cyberbullying

\section{Introduction}


In recent years, technology has developed rapidly, especially after the emergence of the industrial revolution 4.0 trend in Indonesia. The industrial revolution 4.0 is marked by a holistic integration between machines, jobs, or systems through the internet network which then connects all parties in activities on a very wide scale (Zambat, 2019). The 4th industrial revolution is an era where internet technology, information technology and production automation technology are used in an integrated manner to form a system called Cyber Physical Systems (CPS), a system where an entity or physical mechanism is supervised and controlled by a computer-based algorithm, integrated with the internet and its users. One of the products of the industrial revolution 4.0 is social media.

Putri (2019) argues that social media is a medium on the internet that allows users to represent themselves and interact, collaborate, share, communicate with other users, and form virtual social bonds. In social media, three forms that refer to the meaning of social are recognition (cognition), communication (communicate) and cooperation (cooperation). Social media also has several types, characteristics and functions that make this a distinctive feature and make it different from other digital media (Putra, 2019).

Supported by the presence of Smartphones that continue to offer various sophisticated products, users can freely upload content, both photos, videos, send messages, and even express opinions on social media. The content can be easily accessed and viewed by the public so that it is not uncommon for misunderstandings to arise from differences in understanding and viewpoints between social media users in examining the intent of content and resulting in cyberbullying. Cyberbullying is a negative action carried out by a certain person or group by sending text messages, photos, meme images, and videos to someone's social media account with the aim of insinuating, insulting, harassing, discriminating and even persecute individuals (Riswanto \& Marsinun, 2020).

In Indonesia, there are 170 million social media users out of 202.6 million internet users. However, surprisingly, $99.1 \%$ of Indonesian social media users access it via mobile phones. This means, how big is the role of mobile phone penetration for Indonesian social media users. This seems to be what drives the average number of social media accounts owned by Indonesian internet users to be higher than the world average, which is 10.5 accounts per internet user (Budi \& Barito, 2021). The massive use of social media in Indonesia is of course also followed by an increase in cases of impacts arising from the use of social media itself. This is evidenced by the results of a survey from Ditch The Label which shows that in $202160 \%$ of 
teenagers will experience bullying and $87 \%$ of bullying cases occur online (cyberbullying). Another predictable thing that was found was that cyberbullying had increased as a result of all activities turning online as a result of the COVID-19 pandemic.

The issue of cyberbullying on social media is important to discuss because with the increase in the number of social media users during the pandemic, it means that there will be an increase in the number of cases that will occur. Cyberbullying will be very dangerous for a person's mental health, especially the burden that increases due to the Covid-19 pandemic.

There are various motives that provoke someone to do cyberbullying on social media, one of which is misunderstanding. T Misunderstanding itself can be provoked by various factors, one of which is language and its elements. (Azizah, 2021) states that behind a language, there must be an idea. When these ideas are misunderstood, or give rise to multiple understandings, there will be conflict. When a post on social media is misunderstood by a user, other users will definitely be provoked to express their views, which often uses offensive languages. Related to this, those who carry out cyberbullying will also be threatened with being attacked by other social media users. This creates a chain of incidents of cyberbullying that does not stop.

This study aims to find the problem points that cause misunderstandings, by focusing on the impact of the use of language and its elements. The results of this study are expected to answer the following research questions:

1. What are the factors that influence the understanding of social media users towards writing on social media?

2. What are the impacts that occur due to the lack of literacy and the use of language elements that cause misunderstandings in the context of sentences on social media?

3. Which social media is the most vulnerable to being a place of misunderstanding?

4. How do language elements affect the perspective of social media users on an article?

The objectives to be achieved from this research include four things, namely, knowing the factors that influence the understanding of social media users towards an article, Knowing the impact of lack of literacy and the use of language elements on a person's response to writing on social media, Knowing the most vulnerable social media be a place for misunderstandings and their reasons, and Knowing the importance of using language elements in social media to prevent misunderstandings. 
Based on the objectives to be achieved, it is hoped that this research will provide benefits to social media users directly or indirectly. The following are the benefits of this research theoretically and practically.

Theoretically, research is expected to provide benefits in the form of: 1). Provide scientific contributions related to the root causes of misunderstandings that occur on social media so that appropriate solutions can be found to overcome them, 2). Providing insight to teenagers who are active users of social media regarding the importance of literacy and language elements in understanding the context of language on social media, 3). can be a basis for further research related to the problems that occur in social media, especially those related to literacy and the use of language elements.

Practically, the research is expected to provide benefits in the form of: 1). For the author, this research is expected to add insight on how to use social media properly and correctly as a place to express opinions, 2). For educators and prospective educators, this research is expected to increase knowledge and be an effort to socialize about how to use social media properly and correctly as a place to express opinions, 3). For students. As research subjects, students are expected to gain an understanding of the things that need to be considered when using social media and the basic reasons that can lead to differences of opinion that occur on social media, 4). For universities, this research is expected to be additional material so that students are able to analyze the causes that occur and the efforts that can be made to prevent misunderstandings in opinion on social media.

\section{Method}

\subsection{Types of Research Approach}

This research was conducted using a descriptive method with a quantitative approach. According to (Resseffendi 2010:33) said that descriptive research is research that uses observations, interviews or questionnaires about the current situation, where this research is intended to describe the response of society, especially adolescents, regarding the understanding and application of language and literature in social media. Sugiyono (2017:2) said that research methods are basically scientific characteristics to obtain data with certain purposes and uses. Quantitative research is a process of finding knowledge that uses data in the form of numbers as a tool to analyze information about what you want to know. (Kasiram (2008: 149) in his book Qualitative and Quantitative Research Methodology). 
The rationale for using this method is to reveal events, circumstances, and phenomena that arose during the research by presenting facts that actually occurred. In addition, the purpose of using this method is because we want to see the attitudes and views of the community regarding the problems that are the focus of this research, the relationship between variables that will arise, and the differences between existing facts and their effects.

\subsection{Data Sources and Population}

Data is a source of information, also defined as a collection of information needed for decision making. The source of data in the study is the subject where the data is obtained. In this study the authors used primary and secondary data sources. The data directly collected by the author from the first source. The data was obtained by distributing questionnaires to 100 teenagers who were active users of social media with an age range of 13-24 years. Questionnaires were distributed through Google Forms using the technique Self-Administered Questionnaire so that time could collect all the necessary data in a short time.

Population refers to all people, events, or things that are the subject of research. Based on its characteristics, the population must be adapted to the objectives and research problems (Wijaya H., 2020). The population in this study were 100 teenagers who are active users of social media with an age range of 13-24 years.

\subsection{Data Collection Techniques}

Data collection techniques used in this study is to use a questionnaire or questionnaire method. Understanding the questionnaire method according to Arikunto (2006, 151) "Questionnaire is a written statement that is used to obtain information from respondents in terms of personal reports or things they know". Meanwhile, according to Sugiyono $(2008,199)$ "Questionnaire or questionnaire is a data collection technique that is done by giving a set of questions or written statements to respondents to answer. The primary data obtained were obtained using an online questionnaire via Google Form which was distributed to teenagers who are active users of social media within a week (12 November 2021 - 19 November 2021) to reach one hundred respondents.

\subsection{Data Analysis Techniques}


The collected data were analyzed using descriptive statistical analysis techniques. This technique is used to analyze data by describing or describing the data that has been collected as it is without intending to make conclusions that apply to the public or generalizations. This analysis is only in the form of accumulation of basic data in the form of mere descriptions in the sense of not seeking or explaining interrelationships, testing hypotheses, making predictions, or drawing conclusions. This analytical technique is commonly used for exploratory research to reveal and describe research results. In this technique, data will be presented in visual form, namely tables as proof of survey results.

\subsection{Flowchart of the Research Process}

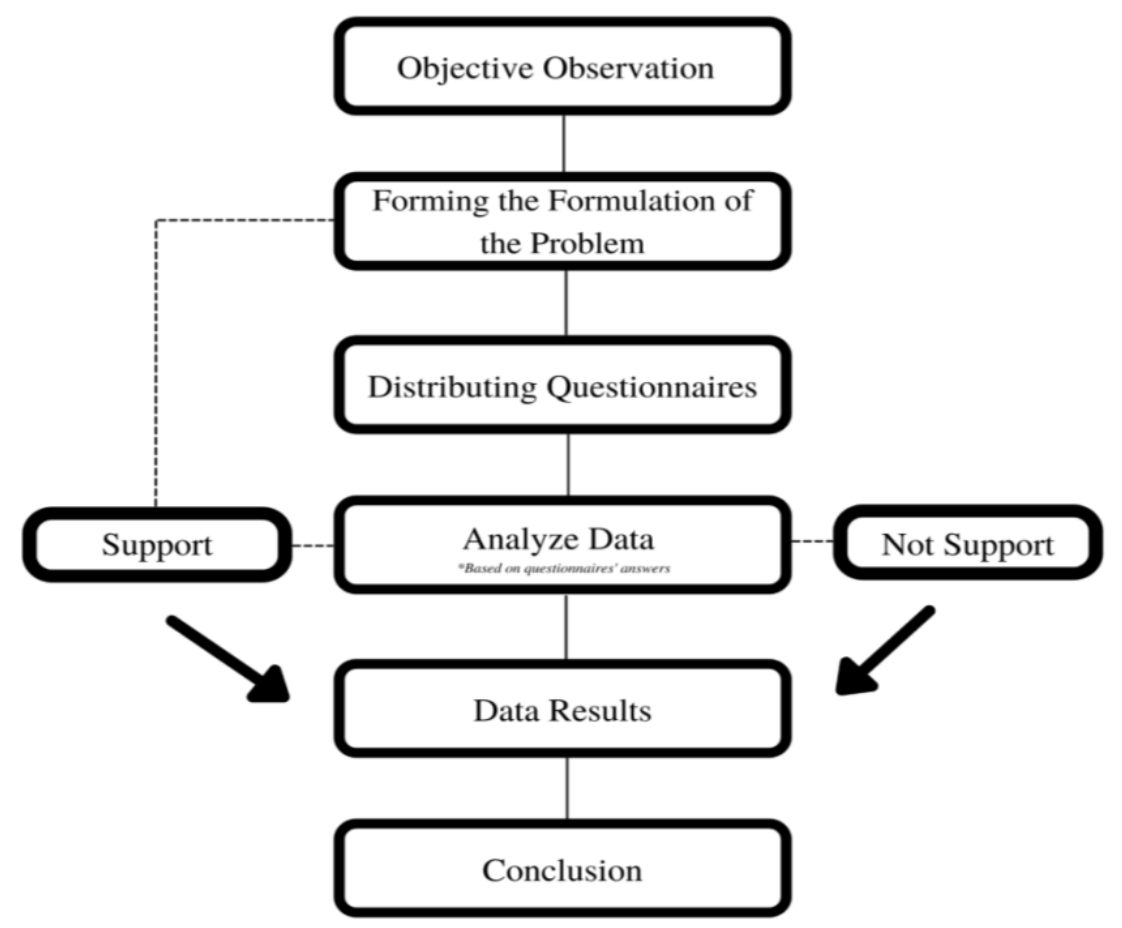

\section{Results and Discussion}

\subsection{Description of Respondents}

The subjects of this research are the young age of social media users with an age range of 13 years to 24 years. This is based on external factors at this time having a considerable influence, especially on adolescents, including the attractiveness of the media, the factors of the need for media and the perceived benefits of consuming media. From the distribution of google form, it was found that 93 respondents with an age range of 19-20 years and 7 respondents aged between 21-23 years.

\subsection{Social Media Used by Respondents}


Technological developments, especially in information and communication, which are developing faster have a positive impact where distance and time are not things that must be considered to have interaction. The developments have led to the presence of social media as a medium on the internet to socialize more quickly and effectively. The presence of social media changes the way people interact with each other with the various services that have been provided. Humans are now transforming from conventional communication to digital communication.

The use of social media among the public, especially teenagers, is currently considered a natural thing. This is in line with data from the Ministry of Communication and Information which shows that as many as 82 million people in Indonesia are internet users. This number makes internet users in Indonesia the 8th largest in the world. With a variety of existing social media, users can easily and freely use the services provided on each of these social media platforms. Budi Gunawan \& Barito Mulyo Ratmono (2021), data We Are Social 2021 shows that $96 \%$ of cellular phone users in Indonesia are social media users. This means that wherever, whenever, and in any situation, social media users can convey their messages through the social media platforms they follow. The following is data on the percentage of social media users used by respondents in this study:

1. $98 \%$ of respondents use Instagram

2. $68 \%$ of respondents use Telegram

3. $58 \%$ of respondents use Twitter

4. $51 \%$ of respondents use TikTok

5. $33 \%$ of respondents use Facebook

6. $16 \%$ of respondents use Quora

7. $11 \%$ of respondents use Whatsapp

8. $8 \%$ of respondents use other social media (Tumblr, LinkedIn, Discord, etc.)

Through the results of this study, we can conclude that Instagram has the most users, as many as $98 \%$. Some people will come to the conclusion that social media with the highest number of users is very susceptible to causing misunderstandings in people's opinions. Then, to find out whether social media with the most users can be an indicator that the medium has the potential to cause misunderstandings or not, it can be seen in table 1 that has been provided:

Table 1. Social Media that Potentially can Cause Misunderstanding 


\begin{tabular}{ll}
\hline Social Media & Percentage \\
Tiktok & $23 \%$ \\
Instagram & $23 \%$ \\
Twitter & $31 \%$ \\
Quora & $0 \%$ \\
Facebook & $15 \%$ \\
Telegram & $0 \%$ \\
WhatsApp & $4 \%$ \\
Most & $1 \%$ \\
All & $3 \%$ \\
\hline
\end{tabular}

This data shows that the social media that has the potential to cause misunderstanding is Twitter, while in Table 2, the data shows that social media The most used by respondents is Instagram. This shows that the most widely used social media does not indicate that it is dangerous (potentially causing misunderstandings). This problem is not found in the large number of users of social media, however, this problem is determined by how the pattern of social media users is used.

\subsection{Factors that Influence The Understanding of Social Media Users}

Reading comprehension is an important component in reading activities, thus, if the reader can successfully take the meaning of the readings that have been read, then the reading comprehension process can be said to be successful (Yesika, Pribowo \& Afiani, 2020). Based on the research conducted, there are several factors that influence the reading comprehension of social media users towards an article. The first factor studied is the choice of words or diction (wording). (Sari and Juita, 2019) Accuracy in word selection is related to the ability to choose 
words that can express ideas appropriately and those ideas can be received appropriately by the reader or listener. The results obtained are 98 out of 100 respondents answered that the choice of diction is very important, while the other 2 respondents answered no.

Language errors are events that are inherent (closely related) in every use of language, both spoken and written. One of the most common mistakes experienced by social media users is the choice of diction. (Sari and Juita, 2019) argued that accuracy in word selection is related to the ability to choose words that can express ideas appropriately and those ideas can be properly accepted by readers or listeners. This means that the choice of diction or words in writing something on social media is certainly very influential on a person's perception or understanding. This is because the choice of diction can affect the meaning of a sentence. Misunderstanding usually occurs when a post on social media uses words with diction that provoke ambiguity. In addition, the choice of diction can also affect the tone or intonation of a sentence. (Khairani, 2020) Every word chosen in mass communication is important. Therefore, the ability to choose diction is very important for social media users. Some words in Indonesian also have different levels of expression, so the selection must be done carefully.

In this study, it was also found that an article on social media was sometimes misunderstood due to an error in the reading tone or intonation of a reader. For example, the use of the word 'yowes' in Indonesian. The word can be read in a nonchalant tone, even though the author wants to express it in a calm tone. Intonation in direct pronunciation is very easy to understand, but this is contrary to the intonation of writing. The intonation of writing is very difficult to understand because writing is much different from speaking. The results of this study showed that $82 \%$ of respondents had experienced errors when interpreting written intonation, while another $18 \%$ admitted that they had never experienced it.

Writing intonation is indeed difficult to understand, but other language elements such as the choice of diction and punctuation can make a person understand the intonation of a piece of writing better. In written language, sentence intonation is symbolized by a dot (.), an exclamation mark (!), and a question mark (?) (Joyo, 2020). As stated by Joyo, in terms of understanding the intonation of reading, there is a significant influence that comes from the use of punctuation marks. In addition, in Indonesia, it is a culture when someone writes a word using capital letters, it means that the intonation of the writing is high or like shouting. From this study, it was found that punctuation and correct use of capital letters are language elements that must be considered when writing something on social media. The intonation of an article 
can be understood by other social media users if the use of capital letters and punctuation is correct. This is evidenced from the two-sentence comparison test in the questionnaire. The respondents were asked to compare two sentences and look for the differences. The results obtained are as follows:

Table 2. Test Finding Differences Between Two Sentences with the Same Context

\section{Differences found by participants}

Differences in sentence form (questioning sentences and imperative sentences)

Differences in sentence forms (question sentences and statement sentences)

Differences in sentence form (direct sentences and indirect sentences)

Intonation

Differences in sentence meaning

Differences in writing

Clarity

No difference

Other

\section{Percentage}

$17 \%$

$7 \%$

$1 \%$

$45 \%$

$10 \%$

$6 \%$

$1 \%$

$1 \%$

$12 \%$

Total

$100 \%$

From the results of this study it can be concluded that the factors What influences a person's understanding in interpreting an article on social media is the choice of diction and the use of language elements (punctuation, capital letters, etc.). These two elements are then important to understand the intonation of a piece of writing. These three elements complement each other; Selection of a good diction must be followed by the use of language elements appropriately so that the intonation of the writing can be understood and the writing does not cause misunderstandings. 
3.4 Impacts Due to Lack of Literacy and Use of Language Elements That Lead to Misunderstanding in Social Media

The Central Bureau of Statistics in 2010 proved that there were 80 million young people aged 14-35 years in Indonesia or 25\% of the total population of Indonesia (232 million people) as active users of social media. Accessibility to the virtual world also shows an extraordinary number. From these data, it can be concluded that the development of social media in this era has experienced extraordinary developments both among teenagers and children.

However, it cannot be denied that social media itself has positive and negative impacts for its users. The positive impact of social media in IT development brings many benefits, such as ease of communication, finding and accessing information. On the other hand, social media also has a negative impact if it is wrong to use this media function. The negative impacts of social networking on adolescents and children include addiction, cyber crime, adolescent attitudes that lead to a permissive attitude towards social deviations, as well as the emergence of other negative things related to the spread of hoaxes and misunderstanding sentences.

Hoaxes, disinformation and misinformation, are currently very important in the discourse related to digital media and social networks. The development of the negative impact of hoaxes is certainly, strongly influenced by the low level of literacy and the use of language elements in social media. This is evidenced by the results of research that has been carried out showing $98 \%$ of respondents think that the lack of literacy skills affects a person's response on the internet.

It is unfortunate how the rapid penetration of social media has not been matched by good literacy skills. In fact, UNESCO noted that in 2012 the reading interest index in Indonesia only reached 0.001 , meaning that in 1000 people there is only one person who reads. This is one of the triggers for the tendency to use which then has negative implications, especially misunderstandings in understanding the context of sentences which can lead to cyberbullying. Phenomena like this are not uncommon on the Internet. In this study, it was found that some respondents often encounter phenomena that occur due to the lack of literacy levels and the use of inappropriate language elements. The data obtained are as follows:

Table 3. Experience of Witnessing Phenomena Happening on the Internet 


\section{Experience}

The emergence of inappropriate responses due

to the lack of literacy levels so that misunderstandings arise in understanding the context conveyed

Easily fooled by news headlines on online sites without reading and understanding the content of the news which is one of the reasons for the occurrence of hoaxes

The emergence of misunderstandings, mainly due to hoax spreaders and readers who do not read the news carefully

Lack of attention to the use of good and correct

grammar on the Internet

Lack of creativity in responding a topic of conversation

Lack of understanding of technology

The emergence of repeated questions because of not reading the instructions/explanations completely

Variety of social media users, ranging from small children, teenagers, to adults

One of the worst impacts of lazy reading is to dwarf people's mindset so they are easily influenced by various negative doctrines and beliefs. This can be seen from how Amanda Michelle Todd, a 15-year-old student in Canada, decided to commit suicide because she couldn't stand the constant bullying she endured through social media. This case began with Amanda's conversation with her new friend on social media in 2010, Amanda was persuaded to show sensitive parts of her body to the perpetrator via webcam. The perpetrator threatened to spread the photo he recorded to Amanda's friends if she was not willing to comply with the perpetrator's request. 
Various insults for Amanda flowed as a hot topic of conversation on social media, and the digital footprint continued to follow Amanda wherever she moved. In the end, Amanda actually died after hanging herself in October 2012. One month before she died, Amanda uploaded a video on Youtube entitled "My Story: Struggling, Bullying, Suicide and Self-Harm" which became the outpouring of suffering that was conveyed by Amanda before she ended her life.

Reviewed once again from the case above, Amanda does not deserve social sanctions which are part of the embodiment of restorative justice for something that is not even her fault. Amanda, who was 15 years old at that time, certainly couldn't think thoroughly about the consequences she did on social media. However, no matter what happens, spreading someone's photo without consent is considered a crime. Amanda should get protection and strength from the people around her for bad events that occur due to irresponsible people. It's ironic to know the fact that the opposite is true. This is because there are still many active users of social media who have low reading levels, so they indifferently catch the news from one perspective, without looking at other perspectives and thinking about the impact that will occur on their actions.

In addition, low interest in reading or literacy levels will cause a person's creativity to not develop. Creative thinking patterns will be realized if the person concerned develops a mindset and is able to respond to the surrounding environment quickly and this can be trained with reading activities. People with low reading interest will find it difficult to catch and respond to a sentence they read, especially if the sentence has the right diction or choice of words that are in harmony (in use) to express ideas so that a certain effect is obtained (as expected), which will lead to misperceptions.

Not only that, the use of random language rules can also have a negative impact on the reader. Social media users tend to mix up text, punctuation, and emoticons in writing their statuses because random writing is considered to exist today. Crystal (2004) explains that the language of the internet or the internet language is the fourth medium after the written language (writing), speech language (speaking), and the language of signs (signing). Text typography that appears and develops on social media is sometimes in the form of words (morphemes), letters (graphemes), and punctuation marks, as well as the use of certain symbols or images. Therefore, the text that appears in the chat room is imagined as if it were speaking.

However, not many people understand this concept. Judging from the number of active social media users who still use punctuation marks and emojis carelessly. The use of punctuation and language elements that are not appropriate will have a negative impact on the 
reader, such as causing misunderstandings or even worse, the emergence of multiple interpretations or multiple understandings (interpretations).

\subsection{How Language Elements Affect Netizen Perspectives}

According to research results that have involved up to one hundred respondents, language elements are an important aspect when writing on social media. This plays a big role because it relates to whether or not a piece of writing is easy to understand. There are many language elements that should be used in writing to make it easier for readers to understand the contents of the reading. The following will show data from the results of the study:

Table 4. Language Elements that Must Be in a Writing/Caption

\begin{tabular}{lc}
\hline Language Elements & Percentage of \\
\hline Punctuation marks & $95 \%$ \\
Emoji & $42 \%$ \\
Use of letters capital & $44 \%$ \\
Use of prepositions & $38 \%$ \\
Use of conjunctions & $59 \%$ \\
Other elements & $9 \%$ \\
\hline Total & $\mathbf{1 0 0 \%}$ \\
\hline
\end{tabular}

From the data above, it can be concluded that there are several language elements that can be used to make it easier to convey something using written media. By not using language elements when writing in cyberspace, it will certainly increase the possibility of misunderstanding the reader's perspective. Misunderstanding can occur because of the ambiguity of writing and the reader cannot know the author's intonation. Therefore, language elements, especially punctuation marks, should not be forgotten when writing. 


\section{Conclusion}

In conclusion, there are several factors that cause misunderstandings between social media users regarding an article, namely the lack of literacy and the use of language elements. The lack of literacy among social media users has an impact on the occurrence of misunderstandings in capturing the intent of an article. In addition to the lack of literacy, misunderstandings are also provoked by ambiguity in writing. The ambiguity of a piece of writing is influenced by language elements in the form of inappropriate diction selection, lack of language elements such as punctuation, errors in the use of language elements, and errors by social media users in capturing the intonation of an article. The research is limited to finding the root of the problem related to things that provoke misunderstandings on social media, not yet reaching the realm of finding solutions. The solution gives a way out to answer the problem. Further research is needed on solutions that can be applied to solve this problem.

Funding: This project received no external funding.

Informed Consent Statement: Informed consent was obtained from all subjects involved in the study.

Data Availability Statement: The data that support the findings of this study are available in the supporting information provided alongside this article.

\section{References}

Joyo, Aceng. (2020). Kalimat Interogatif dalam Bahasa Serawai Masyarakat Seluma. Disastra: Jurnal Pendidikan Bahasa dan Sastra Indonesia, 2(2), 164-170.

Sari, RS, Juita, N. (2019). Analisis Penggunaan (Diksi) Pilihan Kata Oleh Pejabat Legislatif dan Tokoh Partai Tingkat Provinsi Dalam Media Sosial Facebook. Jurnal Bahasa dan Sastra. 6(4).

Khairani, Eva. (2020). Psikologi Komunikasi Humas Aceh dalam Menyikapi Pandemi Korona (Covid-19). Jurnal Peurawi: Media Kajian Komunikasi Islam, 3(1), 103-119. 
Yesika, DH, Pribowo, FSP, Afiani, KDA (2020). Analisis Model Pembelajaran SQ3R Dalam Meningkatkan Membaca Pemahaman Siswa. Jurnal Pendidikan Modern. 6(1).

Mahmur, Hasbullah, \& Masrin. (2020). Pengaruh Minat Baca dan Penguasaan Kalimat terhadap Kemampuan Menulis Narasi. Diskursus: Jurnal Pendidikan Bahasa Indonesia. 3(2).

Riswanto, D., \& Marsinun, R. (2020). Perilaku Cyberbullying Remaja di Media Sosial. Analitika: Jurnal Magister Psikologi UMA, 12(2), 98-111.

Zambot, N. (2019). Identification of geomorphological surfaces using the Isobase method in the basaltic plateau of the middle-lower basin of the Varzea River-RS.

Junita, A. (2021). Kompetensi Stratejik SDM 4.0. SDM Unggul di Industry 4.0, 41.

Putri, RA (2019). Pemanfaatan Aplikasi Wattpad Dalam Memotivasi Siswa Untuk Menulis Cerita. Jurnal Interaksi: Jurnal Ilmu Komunikasi, 3(1), 58-65.

Putra, APT (2019). Pemanfaatan Media Sosial Di Kalangan Mahasiswa (Studi Deskriptif Pemanfaatan Media Sosial Sebagai Sumber Informasi Pariwisata Di Kalangan Mahasiswa Universitas Airlangga Surabaya). (Doctoral dissertation, UNIVERSITAS AIRLANGGA).

Wijaya, H. (2020). Analisis Data Kualitatif Teori Konsep dalam Penelitian Pendidikan. Sekolah Tinggi Theologia Jaffray.

Azizah, IN (2021). Analisis Konstruksi Bahasa Dan Identitas Pada Iklan Produk Mamypoko Dan Sweety: Kajian Multimodal (Doctoral dissertation, UNIVERSITAS AIRLANGGA).

Taturia, DMA (2021). Penggunaan Sufiks Posesif Bahasa Jawa Di Kecamatan Kragan Kabupaten Rembang Jawa Tengah (Doctoral dissertation, UNIVERSITAS AIRLANGGA). 
Mahmur, Hasbullah, \& Masrin. (2020). Pengaruh Minat Baca dan Penguasaan Kalimat terhadap Kemampuan Menulis Narasi. Diskursus: Jurnal Pendidikan Bahasa Indonesia. 3(2)

Kusumawardani, QD (2019). Perlindungan Hukum Bagi Pengguna Internet Terhadap Konten Web Umpan Klik di Media Online. Jurnal Penelitian Hukum De Jure. 19(1)

Valentino, DE (2019). Pengantar Tipografi. Jurnal Politeknik LP3I Bandung. 6(2)

Ginting, J. (2020). Sanksi Kerja Sosial Sebagai Alternatif Bentuk Pemidanaan Dalam Sistem Hukum di Indonesia. Internet Archive Scholar. 19(2)

Nisa, K. (2020). Pemanfaatan Aplikasi KBBI V Pada Materi Menentukan Unsur Kebahasaan. Jurnal Komunitas Bahasa.

Susanto, S \& Darusman, YM. (2021). Menggunakan Media Sosial Ramah Hukum. Jurnal Abdimas .

Husain, MN \& Anggraini, D. (2020). Kampanye Pemasaran Sosial Gemar Membaca Berbasis Media Sosial di Masa Pandemi Covid-19. Prosiding Nasional Covid-19.

Darusman, YM \& Bastianon. (2021). Pentingnya Pemahaman Tentang Kemanfaatan dan Kemudaratan Media Sosial. Abdi Laksana.

Nadeak, B \& Juwita, CP. (2020). Hubungan Kemampuan Berpikir Kritis Mahasiswa dengan Penggunaan Media Sosial terhadap Capaian Pembelajaran pada masa Pandemi Covid-19. Jurnal Konseling dan Pendidikan.

Rianto, P. (2019). Literasi Digital dan Etika Media Sosial di Era Post-Truth, Interaksi: Jurnal dan Komunikasi.

Sudrajat, A. (2020). Apakah Media Sosial Buruk untuk Kesehatan Mental dan Kesejahteraan? Kajian Perspektif Remaja. Jurnal Tinta.

Purawinangun, IA \& Yusuf, M. (2020). Gerakan Literasi Generasi Milenial Melalui Media Sosial. Lingua Rima: Jurnal Pendidikan Bahasa dan Sastra Indonesia.

Suciartini, NNA \& Sumartini, NLPU. (2019). Verbal Bullying dalam Media Sosial. Jurnal Pendidikan Bahasa Indonesia Unissula.

Mutiah, T, \& Albar, I. (2019). Etika Komunikasi dalam Menggunakan Media Sosial. Global Komunika. 
Gunawan, Budi dan Ratmono, Barito Mulyo. (2021). Medsos di Antara Dua Kutub. Jakarta Timur: Rayyana Komunikasindo.

Jamil, M, (2021). Hukum dan Etika dalam Bermedia Sosial. Yogyakarta. Majalah Nusantara IKPMDI.

Firiani, Y dan Aziz, IA. (2019). Literasi Era Revolusi Industri 4.0. Prosiding Seminar Bahasa dan Sastra Indonesia.

Saputra, HN \& Salim, S. (2020). Potret Sikap Mahasiswa dalam Penggunaan Literasi Digital. Jurnal Komunikasi Pendidikan.

Fitrairti, EA, (2019). Urgensi Literasi Digital Dalam Menangkal Hoax Informasi Kesehatan Di Era Digital. Metacommunication: Journal of Communication.

Permata, AD \& Dewi, DA. (2021). Membangun Perilaku Berkeadaban Bagi Siswa dalam Bermedia Sosial Sebagai Implementasi Nilai-Nilai Pancasila. De Cive: Jurnal Penelitian Pendidikan Pancasila dan Kewarganegaraan.

Gani, AG (2020). Pengaruh Media Sosial Terhadap Perkembangan Anak Remaja. Jurnal Universitas Dirgantara Marsekal Suryadarma.

Sartika, A. (2021). Hoaks Terkait COVID-19 dan Islam di Masa Awal Pandemi COVID-19. Institutional Repository UIN Syarif Hidayatullah Jakarta.

Aziz, RM (2021). Literasi Internet Sehat Terhadap Siswa Sekolah Dasar Di Desa Tanjakan Banten. Jurnal Yayasan Pendidikan Riset dan Pengembangan Intelektual. 2(1)

Kristiawan, IWWY, Kurniawan, A., \& Putri, NPRPA (2021). Fasilitas Penunjang Literasi Berbasis Creative Hub di Kecamatan Ubud Gianyar, Bali. Jurnal Online Universitas Warmadewa. 9(1)

Sakinah, DN, Alfaridzi, S., \& Syafri, HP (2020). RUCA CERIA: Sebagai Wadah Inovasi dan Pembentukan Pola berfikir Kreatif Anak. Jurnal Elektronik Universitas Negeri Padang. 8(2)

Aminun, S. (2021). Penggunaan Diksi Pada Wacana Diskusi Haflah Akhirussanah Santri Pondok Pesantren Darul Ulum Medali Sugio Lamongan. E-Jurnal Universitas Islam Darul Ulum Lamongan. 13(1)

Rakhmat, SH (2020). Nilai Budaya Khalayak Digital Dalam Komentar Pada Konten Dakwah di Instagram Hanan_Attaki. Institutional Repository UIN Syarif Hidayatullah Jakarta. 
Esfandari, DA, \& Ridhayani, R. (2019). Analisis Deskriptif Profile Cloning Pada Akun Instagram @Feydown Waspada Love Scammer. Jurnal Elektronik Institut Seni Budaya Indonesia Bandung. 1(1)

Wulandari, S., Sulfary, A., Putri, RRT, Firdaus, A., \& Pradnyawan, SWA (2021). Dampak Pasal-Pasal Multitafsir Dalam UU ITE Terhadap Penanggulangan Cyber Crime di Indonesia. Prosiding Online Universitas PGRI Madiun.

Sudarmanto, HL, Mafazi, A., \& Kusnandia, TO (2019). Tinjauan Yuridis Penanganan Tindak Pidana Cyberbullying di Indonesia. Jurnal Online Universitas Kadiri Kediri. $1(2)$

Rochman, Arif Nur. 2021. Perilaku Netizen Dalam Beretika di Sosial Media. Repository Universitas 17 Agustus 1945 Surabaya.

Grenna-Jennings, Whitney. (2021). "Young People Mental and Emotional Health". Education Policy Institute dan The Prince's Trust.

Gunawan, Budi dan Barito Mulyo Ratmono. (2021). Demokrasi di Era Post-Truth. Jakarta: KPG (Kepustakaan Populer Gramedia).

Hairi, Prianter Jaya. (2019). "Penanggulangan Tindak Pidana Terkait Ujaran kebencian”. Info Singkat. Vol. XI, No. 03/I/Puslit/Februari/2019.

Katharina, Riris. (2019, Agustus). "Insiden Asrama Mahasiswa Papua di Surabaya". Info Singkat. Vol. XI, No. 16/II/Puslit/Agustus/2019.

Kementerian Komunikasi dan Informatika Republik Indonesia dan Katadata Insight Center. (2020). "Status Literasi Digital Indonesia - Survei 34 Provinsi - November 2020". Jakarta: Kementerian Komunikasi dan Informatika Republik Indonesia dan Katadata Insight Center.

Kompas. (2021). "Senat Australia Loloskan RUU Pembayaran atas Konten Media”. Edisi 25 Februari 2021.

Nadeak, Bernadetha. (2020). "The Effectiveness of Distance Learning Using Social Media during the Pandemic Period of COVID-19: A Case in Universitas Kristen 
Indonesia". International Journal of Advanced Science and Technology. Vol. 29, No. 7.

Nadeak, Bernadetha, et al. (2020). "Korelasi Kemampuan Berpikir Kritis Mahasiswa dan Penggunaan Media Sosial terhadap Capaian Pembelajaran pada Masa Pandemi Covid-19”. Jurnal Konseling dan Pendidikan. Vol. 8, No. 2.

Bulele, Yohana Noni dan Tony Wibowo. (2020). “Analisis Fenomena Sosial Media dan Kaum Milenial: Studi Kasus TikTok”. Jurnal Elektronik Universitas Internasional Batam.

Sampurna, Muchammad Bayu Tejo, Tri Cahyo Kusumandyoko, Muh Ariffudin Islam. (2020). Jurnal Sosial \& Budaya Syar-i FSH UIN Syarif Hidayatullah Jakarta. 7(6).

Aprilia, Aprilia, Aat Sriati, Sri Hendrawati. (2020). Tingkat Kecanduan Media Sosial pada Remaja. Journal of Nursing Care. 3(1).

Sudarsono, Feby Fitriani (2020) Pengaruh Social Capital terhadap Pemanfaatan Sosial Media untuk Knowledge Sharing pada Generasi Z. Undergraduate thesis, UIN Sunan Ampel Surabaya.

Alkatiri, Awad bin Muhammad, Zhafira Nadiah, Adinda Nada S. Nasution. (2020). Opini Publik terhadap Penerapan New Normal di Media Sosial Twitter. CoverAge: Journal of Strategic Communication, 11(1), 19-26.

Susanto, MI (2019). Kedudukan Hukum People Power Dan Relevansinya Dengan Hak Kebebasan Berpendapat Di Indonesia. Volksgeist: Jurnal Ilmu Hukum Dan Konstitusi, 2(2), 225-237.

Susanto,Yoyon M Darusman, Bachtiar,Rizal S Gueci, Bambang Santoso. (2021). Menggunakan Media Sosial Ramah Hukum. Jurnal ABDIMAS. 2(1), 72-78.

Dwipayana, Ni Luh Ayu Mondrisa, Setiyono Setiyono, Hatarto Pakpahan. (2020). Cyberbullying di Media Sosial. Bhirawa Law Journal. 1(2). 
Rohmah, Nurliya Ni'matul. (2020). Media Sosial Sebagai Media Alternatif Manfaat dan Pemuas Kebutuhan Informasi Masa Pandemik Global Covid 19 (Kajian Analisis Teori Uses And Gratification). Jurnal Komunikasi dan Penyiaran Islam. 4(1).

Gani, Alcianno G. (2020). Pengaruh Media Sosial Terhadap Perkembangan Anak Remaja. Jurnal Mitra Manajemen.

Aziz, Asma Abidah Al. (2020). Hubungan Antara Intensitas Penggunaan Media Sosial dan Tingkat Depresi pada Mahasiswa. Acta Psychologia, 2(2). 
